\title{
On Taking Back Forgiveness
}

\author{
Geoffrey Scarre ${ }^{1}$
}

Accepted: 19 October 2015 / Published online: 7 November 2015

(C) The Author(s) 2015. This article is published with open access at Springerlink.com

\begin{abstract}
I argue that the effectiveness of forgiveness in the healing of relationships is dependent on both the givers and recipients of forgiveness understanding that once it has been granted, forgiveness is not normally able to be retracted. When we forgive, we make a firm commitment not to return to our former state of moral resentment against the offender, replacing it by good-will. This commitment can be broken only where the forgiving party makes some significant cognitive adjustment to her appraisal of either the offender or the offence, believing that her original forgiveness was granted in error. I reject the view (defended, for example, by Anthony Bash) that forgiveness can lapse or be withdrawn on the basis of a return of hurt or disappointed feelings, arguing that these do not amount to a restoration of the resentment that is extinguished when forgiveness is granted. I contend that a person who 'forgives' and later takes back that 'forgiveness' because certain negative feelings have returned either did not genuinely forgive in the first place or shows that she has not fully grasped the nature of forgiveness.
\end{abstract}

Keywords Forgiveness · Withdrawal of forgiveness · Performative forgiveness $\cdot$ Repentance Reconciliation · Moral judgement · Anthony Bash

\section{Introduction}

Can forgiveness, once given, properly be withdrawn? It seems obvious that sometimes it can. Imagine that unemployed Peter, who has borrowed $£ 20$ from James to buy himself a pair of shoes, gambles the money away at the races. James is angry when he finds out what Peter has done but forgives him when he apologises and shows remorse. Later James learns that Peter's remorse was feigned; he is overheard boasting to friends that he 'had put one across James' and hoped to get more money out of him in the future. Immediately all James's forgivingness vanishes. He tells Peter that since his forgiveness had been drawn from him on false pretences, he now takes it back again.

Geoffrey Scarre

g.f.scarre@durham.ac.uk 
In this case, while James's forgiveness was genuine, Peter's remorse was not. The extent to which forgiveness ought to be made conditional on the remorse or repentance of the wrongdoer has been much debated in the literature on forgiveness, but even writers such as Garrard and McNaughton who defend the propriety of unconditional forgiveness in certain cases (see Garrard and McNaughton 2003, 2010, 117-19) do not suggest that forgiveness is appropriate where an unrepentant offender merely pretends to be repentant. Here the offender is only adding insult to injury. When one repents, notes Linda Radzik, 'One commits or recommits oneself to the right and the good' (Radzik 2009, 67). Peter does no such thing. The forgiveness granted him is granted in error, which its subsequent withdrawal corrects. (A variant on this case would be one in which Peter attempts no deception but James falsely believes him to be repentant and forgives him on that misunderstanding; here, too, James may reasonably revoke his forgiveness when he learns the truth.) ${ }^{1}$

Most instances of forgiveness are not like this. Imagine that on another occasion James loaned money to Mike, who also misused his loan but afterwards was sincerely sorry, apologised and asked James to forgive him. Mike, unlike Peter, satisfies what Charles Griswold describes as a 'baseline condition' for forgiveness, namely that he 'is willing to take minimal steps to qualify for forgiveness' (Griswold 2007, 115). Suppose now that James grants Mike the forgiveness he requests. Could James later change his mind and go back on that forgiveness? Or is forgiveness, in 'normal' cases, where no deception on the part of the offender is involved and the victim does not mistakenly believe the offender to be repentant, once granted, a 'done deal', not to be reversed?

This question, as posed, is ambiguous between the descriptive and the normative. It could be asking whether forgiveness granted by a victim in the kind of circumstances described cannot be taken back, or whether, while it could in principle be withdrawn, such withdrawal would be morally out of order. Certainly it is usual to expect that forgiveness, once granted, will not afterwards be taken back. But this expectation needs unpacking and explaining. Is it that not taking back forgiveness is a necessary condition for forgiving, so that if someone 'takes back' their forgiveness, they reveal that they never really forgave in the first place? Or is it rather that to withdraw one's forgiveness of an injury, while something one can do, constitutes a breach of faith with the forgiven party, who was entitled to regard the matter as closed? Writers who, like Anthony Bash (see Bash 2007, 2015), maintain the possibility of withdrawing forgiveness think it most likely to occur where a victim's injured feelings are revived by certain prompts over which she may have no or only limited control; hence her withdrawal of forgiveness may be wholly or partly excusable. Even if it is a breach of faith and normatively undesirable, it may be more unfortunate than blameworthy.

But is forgiveness ever genuinely withdrawn in such cases (cases, that is, in which the original forgiveness was not based on any deception or mistake in regard to the offender's state of mind)? Or is it the case, rather, that where a victim realises that she no longer feels forgiving towards the offender, she should recognise that she never really forgave him in the first place, though she thought she did? This, I suggest, is a more plausible analysis of such situations. In what follows, I shall argue for the stronger, descriptive thesis that not taking back one's

\footnotetext{
${ }^{1}$ Although James is entitled to withdraw his forgiveness when he learns of his mistake, he may deserve some blame for not informing himself sufficiently in the first place of Peter's state of mind. Because forgiveness is a morally serious affair, it should not be undertaken thoughtlessly, in a frivolous spirit of bonhomie, or in ignorance of ascertainable facts about the offender's attitude to the offence.
} 
forgiveness is a necessary condition for forgiving - that, in other words, forgiveness, once truly granted, cannot be taken back.

Before we look at the arguments in detail, a further example may help to focus the issues. Imagine that Paul has deeply hurt his wife Sue by an act of unfaithfulness. Genuinely repentant for what he has done, Paul apologises to Sue and promises to be a faithful husband henceforth. Sue, believing him sincere, tells him she forgives him. Later, however, Paul, in spite of his good intentions, gives way to temptation again. Sue must now decide whether, and on what terms, she can forgive Paul for his new offence. She may want to subject her husband to a lengthy probation before forgiving him again. But how does she now respond to his original offence? It is probable that the new offence will revive painful memories of the old, making her feel that a closed wound has been reopened. Does this in itself amount to a withdrawal of forgiveness for Paul's original offence? If forgiveness were simply a matter of relinquishing hurt feelings, then the return of those feelings might indeed wipe out that earlier forgiveness. But, as we shall see, forgiveness is more than that since, crucially, it also involves a replacement of moral indignation (a sense that one has been treated with insufficient respect by the offender) by good will and a firm commitment to move on from an offence and to put the past behind (though not necessarily the full restoration of the status quo ante). Forgiveness is a mode of intentionally bringing closure after a relationship has been disturbed or damaged by an offence. Where an offence is repeated, as in Paul's case, the question of forgiveness arises again, but for the fresh offence, not the old one. If Sue genuinely forgave Paul following his first offence, then she put aside her indignation, clearing the slate and making way for a new start. That forgiveness remains a done deal, part of Sue and Paul's past history, even though Sue is now revisited by some of her earlier hurt feelings. (Of course, it is alternatively possible that Sue only thought she had forgiven Paul the first time, her good nature having misled her into believing she had overcome her indignation when she had not. If so, when Paul reoffends, there is no forgiveness for Sue to take back.)

The question of whether forgiveness once given can be withdrawn again is a more interesting one than its relative neglect in the literature may suggest. Indeed, paying close attention to it can throw considerable light on the nature and dynamics of forgiveness. Bringing ourselves to forgive those who have harmed us can be a difficult and lengthy process, but once we have forgiven someone for an offence that process is normally at an end and will not need to be repeated. I shall try to show that the exceptional cases are limited to those in which the forgiving party makes some significant cognitive adjustment to her appraisal of either the offender or the offence, believing that her original forgiveness was granted in error. The mere return of painful memories or hurt feelings on the part of the forgiver, however generated, is not sufficient to undermine that forgiveness.

A final preliminary note. I shall sometimes speak of reversing forgiveness, sometimes of withdrawing or taking back forgiveness. One might also talk about revoking or cancelling or retreating from forgiveness. Despite some minor tonal differences, these expressions all capture the notion of a retrograde movement from a forgiving to an unforgiving state, and I shall use them interchangeably. In all cases there is an abandonment of the commitment to move on from the offence for which forgiveness was initially granted, and a restoration of moral resentment or indignation, though other emotional accompaniments and behavioural resonances can vary. 


\section{Forgiveness as a Form of Transcendence}

The metaphors we use in characterising elements of our experience are often revealing, capturing nuances of understanding that elude attempts at more formal definition. Among the metaphors commonly employed in talking about forgiveness are those of a journey and a gift. Forgiveness can be thought of both as the journey itself and as its destination, as process as well as goal. Unless an offence is very trivial, it usually requires time and effort before the offended party overcomes her anger, resentment and hurt feelings. Archbishop Desmond Tutu quotes the mother of a murdered young girl who strove to forgive the murderer because, as she explained, 'Anger, hatred, resentment, bitterness, revenge - they are death-dealing spirits' (Tutu 1999, 122). In so far as forgiveness involves the elimination of such feelings against the wrongdoer, it may be hard and sometimes impossible to achieve; forgiveness can be a stony road to travel and some think one that ought not to be attempted in the absence of signs of genuine contrition on the offender's part (though this is not a debate I shall engage with here).

The journey towards forgiveness of an offence or an offender may involve false starts, detours and occasional reverses, but once at journey's end one has got beyond the 'deathdealing spirits' - though not necessarily to a point where one would wish to resume any kind of relations with the offender. For forgiveness, though it is often the prelude to reconciliation, is not the same thing, and reconciliation may or may not be a further objective. Thus the mother of the murdered young girl referred to by Tutu may forgive her murderer but want no future contact with him. In some cases there is a resumption of relations with the offender which falls short of a complete restoration: e.g., James may remain friends with Mike after forgiving him for misusing his loan, but refuse to lend him any more money. Here the reconciliation is partial only. Where victim and offender are ambitious to return to the previous status quo, the victim may wish to see additional evidence of penitence and a change of mindset in the offender. While a period of probation might also be imposed as a condition for forgiveness, typically the bar for reconciliation is set higher than it is for forgiveness. As Radzik points out, 'in order to right the wrong, the offender must try to eliminate the [victim's] resentment' $(2009,118)$, and this may require not merely apologising but also making amends for his bad act. This can be done in various ways, e.g., by repairing the damage done, compensating the victim, or voluntarily undergoing punishment or penance. Richard Swinburne observes that a penitent 'constitutes his apology as serious by making it costly' (Swinburne 1989, 84). Demonstrating through action which costs him time and effort that he recognises the gravity of his wrongdoing can also help an offender to traverse the further road from forgiveness to reconciliation. Forgiveness is not inevitably the prelude to reconciliation, but it is plausibly seen as a necessary step on the way to it. ${ }^{2}$

Although the journey of forgiveness is usually conceived as being, like the 'journey of life', a one-way street, the metaphor of forgiveness as a journey does not in itself foreclose the possibility of a retreat from forgiveness or a need to pursue the same trail again. Thinking of forgiveness as a gift that the victim gives to the wrongdoer conveys a stronger sense that there would be something very odd about taking back forgiveness. It is a constitutive rule of gift-

\footnotetext{
${ }^{2}$ This is disputed by Radzik, who suggests that I might be resentful (and thus unforgiving) towards you for leading me on to a dangerous expedition, and yet be 'at the same time trusting you and no one but you to protect my life now that we are in the midst of the adventure' $(2009,118)$. But this does not sound like 'reconciliation' in any usual sense of the word; I rely on you because there is no one else to rely on, but I remain very angry and wholly indisposed to go on any further expeditions with you. (Radzik does propose, however, that reconciliation without forgiveness is 'rare'.)
} 
giving that, while one might voluntarily be given back something that one has first given as a gift, one cannot at will repossess it or demand its return; someone who did not understand this would exhibit confusion over the meaning of gift-giving. Forgiveness is frequently represented as being gift-like because it is not something that can be demanded as of right even by a thoroughly repentant wrongdoer, its bestowal being an act of grace on the part of the victim. To be sure, one might legitimately request the return of a gift that one has given on the basis of false pretences or mistaken information (e.g., one may fairly claim back the tip one gave to Bill for washing one's car when one learns that it was actually his twin-brother Ben who wielded the sponge; this is analogous to James's withdrawing the forgiveness he had mistakenly granted to Peter). But the bestowal of a gift normally puts it beyond the giver's power to recover it at will; and someone who 'gives' an item to another person without grasping this rule of non-return has not succeeded in making a gift. If forgiveness is gift-like, therefore, once it has been granted it cannot be withdrawn.

Arguments cannot, however, be clinched by the use of metaphors and analogies. That there is something gift-like about forgiveness does not prove that the logic of forgiveness must invariably follow the logic of gift-giving. To hold that it did would be mere question-begging. Something more solid is required, and for this we need to look more closely at the role of forgiveness in the moral life. In his sermon 'Upon the forgiveness of injuries', Bishop Butler wrote that 'Malice or resentment towards any man hath plainly a tendency to beget the same passion in him who is the object of it; and this again increases it in the other' (Butler 1970, 81). Resentment breeds resentment, and a cycle of tit-for-tat retaliation ('a long intercourse of ill offices') (ibid.) is provoked when parties are unwilling to forgive. Forgiveness acts as a brake or a buffer that puts an end to mutual antagonism and forestalls further escalation of hostilities; it also, in Butler's view, expresses a due sense of our own fallibility as weak and erring creatures. To these ends, the person who offers forgiveness needs to commit to letting the past be, banishing resentment and ceasing to rake over old injuries. For Butler, the Gospel injunction to love our enemies implies that we should be ready to forgive injuries and move on. To forgive is to transcend the past and move out of its shadow, determining to make a fresh start (though, to repeat a point made above, the 'fresh start' may stop short of resuming one's former relations, if any, with the offender). If forgiveness which is given today might be withdrawn tomorrow, it would show us to be still in thrall to the past.

The kind of moving on that is integral to forgiveness involves a bracketing-off of the past that is not to be confused with forgetting what happened or with pretending that it did not happen. It is not that certain memories are wiped but rather that we cease to dwell on them. Margaret Holmgren has suggested that 'When we forgive, we do not forget the incident; instead we no longer remember it vindictively' (Holmgren 2012, 41). Even this may be insufficient to allow us to move on, since to go on thinking about an offence, even when we do so without vindictiveness, is to remain within its shadow. An offence once committed cannot be uncommitted; but forgiveness consists not in changing the past but in changing one's attitudes to the offender, substituting good will for anger and resentment. When that transition has been made, then bygones must be allowed to be bygones. One could say that forgiveness, once achieved, puts itself out of business. If there is to be genuine transcendence of the past, not only the offence committed but also our forgiveness of it cannot be constantly before the mind. To recall an act of forgiveness one has performed is necessarily to recall the offence that is forgiven, and the respective roles of offender and victim. Particularly where the parties look beyond bare forgiveness to the resumption of a warmer relationship, both need to move not just beyond the offence but also the forgiveness. Restoring a relationship of moral 
equals between people who remained typecast as forgiver and forgiven would be a tall order. Admittedly, when a person has been deeply wounded, forgiveness does not always bring the sort of closure that it ideally does. Sometimes this may be because one is unsure whether one did right to forgive, or forgive when one did. Such may have been the case with Gordon Wilson, who magnanimously forgave the IRA bombers who killed his daughter at Eniskillen in Northern Ireland in 1987. Wilson is said subsequently to have 'struggled with the original act of forgiveness, with the pain and grief that lay behind his choice to forgive' (Bole et al. 2004, 65; quoted in Bash 2007, 66).

Detachment of the sort needed for satisfactory forgiveness does not involve pretending that the offence never occurred, nor need it 'wipe the slate clean' in the sense of restoring the status quo ante, taking the offender and the victim back to exactly where they were before the offence. Garrard and McNaughton rightly remark that if 'wiping the slate clean' 'means that when we forgive we must forget the crime, or behave as if it had never happened, or allow it to make no difference to how the offender is treated, then there often seems to be something deeply wrong with that' (Garrard and McNaughton 2010, 21). But Garrard and McNaughton acknowledge the point previously made when they concede that in one important respect what happens in forgiveness is 'something like wiping the slate clean': for 'If I have forgiven, then I shouldn't keep bringing the offence up, and I won't be able to go on holding it against the offender' (ibid., 90). Holmgren, likewise recognising the need for forgiveness to involve a certain kind of oblivion, sums the position up neatly: 'When we forgive, we make peace with the past and no longer feel a need to concern ourselves with it, beyond drawing on it in ways that are beneficial in planning for the future' (Holmgren 2012, 41).

That forgiveness excludes any see-saw alternation of good will and resentment enables it to play a vitally important role in the moral life of erring human beings. If someone who purports to have forgiven an offender later has and voices second thoughts, the offender will very reasonably question whether he was truly forgiven before; he may also feel let down if he thinks has done nothing to warrant the reversion to his former status. Here it might be suggested that because forgiveness involves undertaking to cease bringing up the offence and one's subsequent forgiving response, one breaks that commitment if one later withdraws one's forgiveness. But alternatively, and, I think, more plausibly, the correct reading of the situation is that forgiveness was never fully accomplished in the first place; although the victim may have been sincere in believing she had conquered her resentment and could commit to putting the offence behind her, she was in fact still on the journey thither (and, indeed, might never fully accomplish it). The commitment involved in forgiving is a strong one, amounting to a promise to let bygones be bygones, and like any promise, it should be able to be trusted. If it were merely a casual undertaking, one made lightly, provisionally or without firm assurance of fulfilment, then forgiveness would become a much less valuable practice (if it survived at all), quite unable to play the significant role it now does in our moral relationships. Told today that one was forgiven for some offence, one could never be sure one would remain forgiven tomorrow. Hence where a victim is not (yet) in a position to make the robust and trustworthy commitment involved in forgiving, he or she is not yet ready to forgive.

Some writers have made a distinction between what Marilyn McCord Adams has called 'performative forgiveness' and 'forgiveness from the heart' (Adams 1991, 294). Although the distinction is valid and useful, it is a mistake to think that 'performative forgiveness' and that which is 'from the heart' are different species of forgiveness. Normally, where one sincerely utters the words 'I forgive you' one both performs a certain speech act and signifies that one has undergone a change of heart towards the offender. The words express a commitment to 
move on and to act in future in a non-resentful manner, and (as is the case with any promise) one should not say them unless one is sure that one can live up to them. (Note that even when one forgives inwardly rather than openly and explicitly, something corresponding to the performative element is present, in that one commits oneself to moving on.) According to W.R. Neblett, saying 'I forgive you' in certain circumstances is understood as making a quite definite promise to let go of the past. Therefore, he suggests, where Mary has said these words to John, the latter has a right to complain if Mary later behaves to him in a resentful and uncooperative spirit. Reminding Mary that she has already forgiven him for his offence, John may persuade her that she cannot now go back on her words (Neblett 1974, 269). Neblett supposes that Mary has still to forgive John from the heart but does not - on account of the performative nature of the words she says to John - have on that ground a justification for withdrawing them. When John protests that Mary should not go back on her words, he reminds her of the promise she has implicitly made by uttering 'I forgive you.' To say 'I forgive you' and afterwards not live up to those words or act as if one had not said them is to renege on one's promise.

Neblett's analysis may apply better to acts of formal pardon (where one says 'I pardon you' or equivalent words) than it does to forgiveness. ${ }^{3}$ The relevant difference is that issuing a formal pardon, as distinct from granting forgiveness, is only contingently associated with any affective attitudes. An authority figure can let a subordinate off the punishment usually attached to some offence without any motions of the heart at all. Absent any further misdemeanours on the part of the pardoned, the subsequent withdrawal of pardon and imposition of penalties is a simple, and blameworthy, breach of promise: certain words, such as 'I pardon' were said, and those words should have been adhered to. But to say 'I forgive you', while it similarly makes a strong commitment to alter attitudes and actions, is not merely performative but also descriptive, since it conveys that a change of heart (an extinction of resentment) has taken place. Where that change has not occurred, or is incomplete, the words ought not to be spoken, on pain of being misunderstood. Mary could tell John that she is trying to forgive him, or that she no longer feels as much resentment against him as she did; but if she tells him that she forgives him before her resentment has given way to good will, she says more than she presently should. If, misreading her own condition, she utters the words and later discovers she has spoken prematurely, John will justifiably see this as a volte face. But Neblett's explanation that this is because Mary has already granted performative forgiveness can be challenged. Rather, she has mistaken her own attitude to John and uttered the words 'I forgive you' before she has achieved a state of forgiveness. She may have been trying to force the pace because she was creditably anxious to restore good relations with John. Even so, her words were not ideally chosen.

\section{When Forgiveness May be Withdrawn}

It was proposed above that forgiveness should be thought of as the goal and termination of a psychological and moral process that, once attained, constitutes a form of transcendence of the past. But could this account be accused of portraying forgiveness in an over-idealised or romanticised light that ignores the untidiness - the essential messiness - of real-life moral

\footnotetext{
${ }^{3}$ For a more detailed analysis of performative (here called 'declarative') forgiveness that is in keeping with the outline given here, see Pettigrove 2012, 9-12.
} 
relationships? Even allowing that some instances of forgiveness do approach the ideal of transcendence in the sense described, how realistic is it to suppose that forgiveness is generally like this, and that human beings are good at 'moving on' without ever having a resumption of resentment? According to Bash, 'It is possible to forgive one day and not the next. ... One can be forgiving and unforgiving at the same time' (Bash 2007, 166). These propositions should be questioned. The sort of transcendence required for forgiveness does not require a wiping of the memory banks, or an elimination of all hurt feelings; rather, what matters is that a past offence can be recalled without evoking a fresh burst of anger or of regret that peace has now been made with the offender. And this is surely not a very rare phenomenon. Bash is right that in some moods one may be readier to forgive than in others; but this does not legitimise the taking back of forgiveness (and while one could be in two minds as to whether or not to forgive, this is not to be 'forgiving and unforgiving at the same time').

To be sure, bringing ourselves to forgive, especially where we have been the victim of a major offence, is rarely easy. But it does not follow from the fact that forgiving can be hard that it must always be a frail and sensitive plant, liable to be destroyed or damaged by a change in the weather. Forgiveness is not just a matter of emotions which are here today and gone tomorrow. Rather it requires a process of cognitive and affective development by the victim that issues in a conscious decision to turn away from the past offence and commence looking on the wrongdoer in a kindly rather than a resentful manner. In the ideal case, a repentant offender participates with the victim in the process of readjustment, both agreeing to put the past behind them and dwell no more on either the offence or its forgiveness. Forgiveness, we noted above, can be made conditional on the fulfilment of certain conditions by the offender. Nevertheless, someone who said, 'Well, I fully forgive you today but I warn that I may feel quite different about it tomorrow' would show that he or she did not understand what sort of commitment is involved in forgiving.

Still, there are instances which appear to show that forgiveness is less robust and more reversible than this account would allow. In the remainder of this section I describe three examples of situations in which forgiveness is apparently taken back. I shall argue that in the first, the reversal is merely seeming and not real. Here what may initially appear to be a withdrawal of forgiveness for an offence turns out to be something different, namely the advent of an unforgiving stance towards a different offence (or, more precisely, the offence differently contextualised). In the next two examples, appearances and reality are more closely matched. They develop the point made at the beginning of this essay, that forgiveness can be withdrawn in (and, I believe, only in) the special case where it has been granted in error. The fact that forgiveness can be taken back in the light of a significant alteration in the victim's moral evaluation of the offence or the offender demonstrates that the claim that forgiveness is never reversible is too strong.

Example 1: The Domestic Violence Incident Bill is normally a placid and good-natured husband but one evening, after a bad day at work, he uncharacteristically strikes his wife Jane. Afterwards, horrified by what he has done, he apologises and promises never again to allow his temper or his troubles to get the better of him. Jane, who is profoundly shocked, cannot immediately forgive Bill, but as the days pass and she observes his evident contrition, she is finally able to do so. Shortly after this, their seven-year-old son Tom begins to show signs of psychological disturbance, becoming moody and surly and prone to sudden fits of violence. On investigation it transpires that Tom had witnessed his father's striking his mother and been traumatised by the experience. When she learns of this, Jane feels renewed resentment against 
her husband. Should we say that Jane has now withdrawn her forgiveness of Bill? Yet despite the return of resentment, the change in her is not correctly described as a withdrawal or cancellation of her previous forgiveness. To capture what is going on, it is necessary to provide more fine-grained descriptions. What Jane originally forgave Bill for was the hurt and insult he had inflicted on her; what she later resents is the harm that Bill, by striking her, has caused to their son Tom. Jane could continue to feel forgiving of Bill on her own behalf while remaining resentful at what he has done to their child. ${ }^{4}$

Commonly, moral offences have multiple ill effects. This matters when we speak about forgiving an offence, because an offence may be forgiven under one aspect but not another, or in respect of some, but not all, of its consequences. In the present example, Bill's original misdeed harms Tom as well as Jane. The pain that Jane feels as a wife is distinct from that which she feels as a mother, and Bill's blow means something different to her in each of these roles. When the contextualisation of an act alters, the question of forgiveness may need to be faced afresh. In view of the intricacy of human affairs, it is unsurprising that one complex of act-and-effects may sometimes be forgiven where that same act in connection with a different set of effects is not.

Example 2: The Backsliding Offender Milly and Margaret have long been colleagues in an office. Margaret is unjustly resentful that Milly has been promoted faster than she has been, and spitefully reports to their common superior some minor error that Milly has made. Milly is hurt by Margaret's disloyalty and tells her so, since the error could easily have been remedied without informing their chief. Margaret, who is not really ill-natured, is sorry for what she has done, and apologises. Milly therefore forgives her and proposes that they should treat the incident as closed. But later Margaret falls again to brooding on what she sees as their employer's unfair favouring of Milly, and decides she was right all along to report Milly's slip. 'For,' she says to herself and others, 'it was about time that Little Miss Perfect got her come-uppance.' When Milly learns from other colleagues that Margaret now repents of her repentance, her hurt and anger are revived.

Perhaps Margaret's ostensible repentance for reporting Milly's slip was never sincere, even if Margaret herself believed it was, not wishing to think of herself as a jealous woman. If Milly concludes that she was taken in by false appearances, she is likely to withdraw her forgiveness. This withdrawal fits the standard pattern, being both provoked and justified by the recognition of a cognitive error by the forgiving victim. But it is also possible that Margaret's original repentance was entirely sincere, despite its transience. If this is how Milly reads Margaret, she has no good reason to withdraw her original forgiveness, though she still has to reckon with Margaret's latest bout of spitefulness. Because Margaret has proved to be fickle and a backslider, Milly may find it considerably harder to forgive her a second time. ${ }^{5}$

\footnotetext{
${ }^{4}$ It may be doubted whether Bill can be forgiven at all for what he has done to Tom (as distinct from Jane as Tom's mother). For it is unclear to what extent young children, as psychologically and morally immature individuals, can grant forgiveness. But it is not clear, either, that anyone else (including their parents) can grant forgiveness on their behalf. This is not the place to enter the debate over the possibility of 'proxy' or 'third-party' forgiveness, but it may be remarked that the parity in the relationship (namely, parenthood) in which both Jane and Bill stand to Tom makes it additionally hard to see how either could grant forgiveness to the other on behalf of their child.

${ }^{5}$ Margaret's return to spitefulness may persuade Milly that her earlier repentance was bogus even if it had actually been genuine. But if Milly withdraws her forgiveness at this point, her error is very excusable, given Margaret's puzzling and inconsistent behaviour.
} 
Example 3: The Forgiver Who has Second Thoughts Miles, a tolerant and easy-going person, frequently finds himself the butt of Jules' somewhat warped sense of humour. When Miles is about to drive to the airport to catch a plane to take him to an important meeting, Jules mischievously removes a vital part from Miles's car, causing him to miss his flight. When a laughing Jules later presents the missing part to Miles, Miles is very angry. But Jules replies that he is sorry for what he did - he did not realise the meeting mattered so much to Miles and, besides, it was just a bit of fun, not an act of malice. 'Surely you can take a joke,' he says to Miles; and Miles is persuaded that he both can and should. He therefore forgives Jules, adding that he hopes that he will desist from playing similar tricks in future.

Later, in a cool hour, Miles reflects again on Jules' joke and his response to it. He now considers that he has let Jules off too lightly. Jules' 'bit of fun' was actually a mean and unfriendly trick and one that, despite his protestations, smacked of malice. Even if Jules was sorry for his act, his sorrow, Miles considers, could be no deeper than his own estimate of his 'offence' as a possibly ill-judged joke. Suppose that Miles concluded his last conversation with Jules by saying, 'All right, I forgive you; it was a silly thing to do and you mustn't do it again, but we'll say no more about it.' In that case Miles may feel that he has tied his own hands and cannot, without breach of his (albeit premature) word, take Jules again to task for his deed. But he may nevertheless no longer forgive Jules. He withdraws his forgiveness because he judges that his earlier graciousness to Jules was ill-deserved. Unless Jules, too, reconsiders his 'joke' and comes to Miles with a more adequate apology and acknowledgement of his fault, then Miles may continue to judge him unworthy of forgiveness.

This case differs from that of Milly and Margaret in that Miles, unlike Milly, forgave too quickly, without proper forethought. Milly forgave Margaret because she was impressed by the signs of contrition she saw in her (whether genuine or not). Some writers on forgiveness, including Garrard and McNaughton (2010), Calhoun (1992) and Pettigrove (2012) have argued that granting forgiveness to an undeserving offender can be not only permissible but positively virtuous. However that may be, the problem with Miles is not that he grants forgiveness to an undeserving Jules, but that he forgives before he has fully thought the situation through. While his quickness to forgive indicates good nature, it testifies less well to his good judgement. Miles's later reflections convince him that he should not have forgiven Jules so lightly, and that more is required from Jules before forgiveness is in order. By forgiving Jules too readily, he has done less than he might to discourage him from playing further practical jokes and undermined the force of his parting remark that Jules should refrain from them in future. Even if Miles concedes that there may be circumstances in which forgiving an unrepentant offender can be meritorious (e.g., where an offender has died before he has had an opportunity to repent), he does not, on mature consideration, regard this as being one of them. David Konstan has suggested that 'serious' forgiveness is forgiveness that has been fully thought through before being granted, and that serious forgiveness is therefore never or rarely withdrawn on the basis of any second thoughts (Konstan: private communication). This seems right. Still, in being too quick to forgive Jules, Miles revealed a fundamentally kind heart.

\section{The Fragility of Forgiveness?}

The two preceding examples illustrate how forgiveness can be cancelled or withdrawn where the offended party considers that it has been given by mistake. Relevant errors can 
conveniently be gathered under three heads. Forgiveness may appropriately be withdrawn in the following circumstances: a) where the offended party comes to judge that she has granted it too lightly; b) where she learns that the offender's 'repentance' was feigned or insincere; or c) when new evidence appears which reveals the original offence in a new light. Category c) may be regarded as including b) as a special case but it also covers situations (not represented in our previous examples) in which the original characterisation of the offence is revised (for instance, I forgave you for what I thought was a mere careless treading on my toe, but I withdraw my forgiveness when I learn that you were maliciously trying to stamp on my corns).

But are these really the only kinds of case in which forgiveness is ever taken back? Some may think that the account so far pays too little attention to the psychology of forgiveness. Are there no situations in which we find our forgiveness of offenders leaving us whether we would have it so or not? Our forgiveness may have been well considered and granted in full knowledge of all relevant facts; we might also have been particularly moved by the evident contrition of the offender. Yet the heart does not always move in step with the head. Hearts, at least according to the poets, are notoriously inconstant organs. Romeo, who loves Juliet today, loved Rosaline yesterday. Anger and resentment, like love and desire, can wax and wane and wax again. The negative feelings we entertain for someone who has wronged us may diminish while our attention is engaged elsewhere but return in force when the offender or the offence come back to mind. That being so, one might expect that forgiveness would also come and go, according as our resentment ebbs and flows.

According to Anthony Bash, who takes this view:

It is surely foolish to say "I forgive you" and assume that nothing in the future might arise that will reopen the wounds of the past or mean that one has to renew the work of forgiving. ... Additionally, many of us will have seen someone, or returned to a place, or heard a piece of music that brings back memories about a former unpleasant experience. If that experience relates to having been wronged, one might find that one needs to reengage with having to forgive. ... I suggest, therefore, that forgiveness can best be thought of as reversible and revocable, though it should not be offered with this possibility in mind $(2015,47)$.

Bash concludes that we should always look on forgiveness as 'provisional', even though when we offer it we intend it to be an unconditional gift (ibid., 46-49). Arguably, Bash weakens his position unnecessarily by the use of the word 'provisionally'. No offender is likely to be very satisfied to receive forgiveness which is understood to be merely provisional and hostage to the forgiver's changing moods. Since Bash does not deny that forgiveness involves a commitment to put the past behind, he would do better to hold that forgiveness is normally given without strings attached, while also affirming that the commitment can break down in practice. And indeed he gestures towards this stronger position when he concedes that it would be unsatisfactory for a victim to say to an offender, 'I forgive you for the wrong you have done me, but I may, if I wish, revoke the forgiveness' (ibid., 48). However, the instability of Bash's position is evident when he implausibly postulates as a 'paradox' of forgiveness that 'it is both irrevocable and revocable at the same time' (ibid.).

The experiences that Bash asks us to consider remind us how disruptive, unsettling and hard-to-heal some injuries can be. Painful feelings of hurt or the sense of disappointment or betrayal that can accompany victimhood may linger for a long time, sometimes lying dormant but ready to erupt again when memory is suitably stirred. Bash is undoubtedly correct that painful feelings can come and go as recollection of former injuries returns or retreats. 
However, it is much less clear that he is right to describe what is happening as a waxing and waning of forgiveness, questionably construed by him as a process of indefinite duration in which we move in and out of a forgiving stance according to the pattern of memory and oblivion.

Holmgren has suggested that 'the motivational component of an attitude of resentment, in its more general form, consists of a desire for the moral order to be restored' $(2012,30)$. Such moral resentment (for one can also feel immoral resentment, as when Margaret resents Milly for her faster promotion by their employer) arises in a person when she believes that 'the offender has failed to accord [her] sufficient concern and respect' (ibid.). Resentment thus combines a cognitive and an affective component: a recognition that one has been treated with a lack of the respect due to one as a member of the kingdom of ends, and a feeling of indignation at being treated in that inappropriate manner. When we forgive, we move beyond our sense of indignation with the offender and replace it by a positive spirit of goodwill. There is also, as Holmgren, and also Pamela Hieronymi (2001), have emphasised, a cognitive change. Instead of focusing on the offender as the source of insult or injury, we move to seeing him or her as a fallible, imperfect human being who is capable of good as well as bad. Forgiveness, writes Holmgren, 'includes an acute awareness that, like us, the offender is subject to various needs, pressures, and confusions in life and is vulnerable to error' (2012, 33). Forgiving, as noted earlier, is not always the prelude to reconciliation, and the forgiven offender may still be expected to demonstrate contrition by apologising, making amends, paying compensation or undergoing punishment or penance. Nevertheless, when we forgive we signal our recognition that the offender is a member of the kingdom of ends whose well being matters to us, and towards whom we are now prepared to exercise a practical goodwill.

To forgive is to determine to make a new start, committing ourselves to look forward rather than back. If forgiveness is to play its vital role of lifting relationships off the rocks of offence and ill will, then it cannot be allowed to be subject to the ebb and flow of the tides of feeling. While Bash is right in his Proustian claim that a variety of sometimes subtle prompts can revive the painful memories and distressful states associated with past injuries, this does not, as he thinks, show that forgiveness comes and goes according as our moods shift, or that it is only ever 'provisional'. When Sue's husband Paul is unfaithful to her for a second time, the painful memories this revives do not amount to a withdrawal of her forgiveness for his first offence. That episode was dealt with when Sue, seeing Paul's genuine contrition, put away her indignation and determined to act towards him with her former good will. (Sue might alternatively have offered Paul forgiveness on the express condition that he should demonstrate his faithfulness over some specified period; in that case, his failure to fulfil the condition means that the forgiveness was always only pending, not that it was given and subsequently withdrawn.) To forgive does not require relinquishing for ever all negative feelings that ensue on being the victim of an offence. If it did, then forgiveness would be beyond the capacity of beings with a psychological make-up like ours. Forgiveness is of vital importance in the moral life precisely because it provides a way of moving forward from an offence even where feelings of hurt or disappointment linger or are liable to return. It does this by putting aside moral indignation or vindictiveness in favour of good will, reframing the offender as a fallible human being (a reframing ideally accompanied by a recognition of our own fallibility), and determining to look forwards rather than back, treating the offender not $a s$ an offender but as a 
moral agent and equal. To complete this process, I have suggested, not only the offence but also the forgiveness should be allowed to sink into the past, so that the parties can move beyond looking on each other in the roles of forgiving victim and forgiven offender.

None of this, of course, may be easy to achieve. To suppose, however, that for a victim to forgive, or to grant forgiveness that is more than merely partial or 'provisional, it is necessary for him or her to move permanently beyond all negative feelings aroused by the offence is to represent forgiveness as even more challenging than it is - and probably beyond normal human capacities altogether. Forgiveness requires a substitution of moral indignation by good will towards the offender, so that one henceforth feels and displays no resentment or hatred but instead a spirit of amity. But this transformation is quite consistent with remaining shocked, hurt, disappointed or let down by the offender's actions, or resuming those feelings in the future. Forgiveness is not hostage to such feelings, although once it is granted it may become easier (if not necessarily easy) to counter and eventually despatch them than if the parties had stayed at loggerheads.

It would be depressing to think that forgiveness was capable of suffering the reverses that Bash claims it to be subject to. While he is right that a victim's negative feelings may exhibit considerable staying-power, he fails to show that their return can cause forgiveness to dissolve, requiring the banishment of resentment and ill-will to be attempted all over again. We walk the hard path to forgiveness in the belief that once we have reached the goal we will not have to do so again. To think of this as a Sisyphean task of pushing uphill a heavy stone which is forever liable to roll down again, requiring a repetition of the process, is a dispiriting conception that could well make us wonder whether forgiveness was worth the effort. Recipients of forgiveness, too, would take less satisfaction in being forgiven if they thought that it might later be taken back. If forgiveness is really as insecure, unstable and potentially revisable as this, it scarcely deserves the praise that moralists have conventionally bestowed on it.

Forgiveness 'works' in the healing of relationships because the givers and recipients of forgiveness understand it to involve a commitment that will not normally be broken or retracted. I have argued in this paper that, when we forgive, we make a commitment not to return to our former state of resentment and to turn over a new leaf with the offender. This commitment is legitimately broken only where a subsequent reappraisal of the offence or the offender convinces the forgiving subject that forgiveness should not originally have been bestowed. To be sure, forgiveness that is still in the making may proceed by fits and starts, its progress marked by advance and reversal according as resentment or good-will attains the upper hand. But the achievement of forgiveness marks the end of this process and the attainment of a new equilibrium. It is not always easy for the forgiving subject to be sure when this point has been reached. Both the thought that one ought to forgive and the desire to be through with the struggle can fool one into thinking one has advanced further than one has. So we are sometimes surprised and disappointed to find that we have made less progress than we had thought. When this happens, the readiness with which resentment re-emerges is compelling evidence that our journey to forgiveness has been incomplete. But such setbacks should not deter us from striving to forgive, where our judgement tells us that forgiveness is called for. If at first we do not succeed, we should go on trying. 
Acknowledgments I am grateful to David Konstan, Anthony Bash and particularly to two anonymous referees for the journal for their comments on earlier versions of this paper.

Open Access This article is distributed under the terms of the Creative Commons Attribution 4.0 International License (http://creativecommons.org/licenses/by/4.0/), which permits unrestricted use, distribution, and reproduction in any medium, provided you give appropriate credit to the original author(s) and the source, provide a link to the Creative Commons license, and indicate if changes were made.

\section{References}

Adams MMC (1991) Forgiveness: a Christian model. Faith Philos 8:277-304

Bash A (2007) Forgiveness and Christian ethics. Cambridge University Press, Cambridge

Bash A (2015) Forgiveness: a theology. Cascade Books, Eugene

Bole W, Christiansen D, Hennemeyer RT (2004) Forgiveness in international politics: the alternative road to peace. US Conference of Catholic Bishops, Washington

Butler J (1970) Butler's fifteen sermons preached at the rolls chapel. In: Roberts TA (ed) SPCK, London

Calhoun C (1992) Changing one's heart. Ethics 103:76-96

Garrard E, McNaughton D (2003) In defence of unconditional forgiveness. Proc Aristot Soc 104:39-60

Garrard E, McNaughton D (2010) Forgiveness. Acumen, Durham

Griswold CL (2007) Forgiveness: a philosophical exploration. Cambridge University Press, New York

Hieronymi P (2001) Articulating an uncompromising forgiveness. Philos Phenomenol Res 62:529-555

Holmgren MR (2012) Forgiveness and retribution: responding to wrongdoing. Cambridge University Press, New York

Neblett WR (1974) Forgiveness and ideals. Mind 83:269-275

Pettigrove G (2012) Forgiveness and love. Oxford University Press, Oxford

Radzik L (2009) Making amends: amendment in morality, law, and politics. Oxford University Press, New York Swinburne R (1989) Responsibility and atonement. Clarendon, Oxford

Tutu D (1999) No future without forgiveness. Rider, London 